\title{
PEMANFAATAN METODE WEIGHTED K-NEAREST NEIGHBOR IMPUTATION (WEIGHTED KNNI) UNTUK MENGATASI \\ MISSING DATA
}

\author{
Penerapan pada Data Indeks Produksi Triwulanan Industri Mikro Kecil (IMK) \\ Tahun 2016-2019
}

\section{Utilizing Weighted K-Nearest Neighbor Imputation (Weighted KNNI) Method to Overcome Missing Data}

\author{
Iman Jihad Fadillah ${ }^{1}$, Chaterina Dwi Puspita ${ }^{2}$ \\ Badan Pusat Statistik ${ }^{1}$ \\ Badan Pusat Statistik ${ }^{2}$ \\ Jakarta Pusat, DKI Jakarta, Indonesia \\ E-mail: jihadiman22@gmail.com
}

\begin{abstract}
ABSTRAK
Pada tahun 2020, hampir semua negara di dunia menghadapi wabah COVID-19, termasuk Indonesia. Salah satu dampak yang terjadi karena adanya pandemi COVID-19 adalah terhambatnya kegiatan statistik, seperti tertundanya atau berhentinya pelaksanaan pengumpulan data survei dan sensus serta pengumpulan data lainnya. Sementara itu, untuk memenuhi permintaan dan kebutuhan data selama masa pandemi COVID-19, badan statistik nasional harus tetap melakukan pengumpulan data dan menyediakan data statistik. Oleh sebab itu, badan statistik nasional harus melakukan adaptasi untuk kegiatan proses sensus dan survei yang dilakukan, seperti mencari mode pengumpulan data alternatif, mengurangi ukuran sampel, memodifikasi desain sampel, mengurangi item pertanyaan di kuesioner, atau lainnya. Berdasarkan uraian tersebut, adaptasi kegiatan pengumpulan data sensus/survei yang dilakukan pada masa pandemi COVID-19 akan berpengaruh pada kualitas data yang dihasilkan. Salah satunya adanya missing data. Untuk mengatasi masalah missing data, salah satu metode yang dapat digunakan adalah imputasi data. Salah satu jenis metode imputasi berbasis machine learning yang sering digunakan adalah Weighted KNNI. Metode Weighted KNNI memiliki akurasi yang secara umum lebih baik dibandingkan kedua metode imputasi lainnya (Unweighted KNNI dan Mean Imputation). Berdasarkan hasil tersebut yang dilihat dari akurasinya, metode Weighted KNNI dapat digunakan sebagai salah satu solusi untuk menangani ketidaklengkapan data pada masa pandemi COVID19 sekarang ini.
\end{abstract}

Kata kunci: missing data, KNNI, imputasi

\section{ABSTRACT}

By 2020, almost all countries in the world will face the COVID-19 outbreak, including Indonesia. One of the impacts that occurred due to the COVID-19 pandemic was the obstruction of statistical activities, such as delayed or stopped carrying out survey and census data collection and other data collection. Meanwhile, to meet the demand and data needs during the COVID-19 pandemic, the national statistical agency must continue to collect data and provide statistical data. Therefore, the national statistical agency must adapt to the census and survey process activities carried out, such as finding alternative data collection modes, reducing sample sizes, modifying sample designs, reducing question items in questionnaires, or others. Based on this description, the adaptation of census / survey data collection activities carried out during the COVID-19 pandemic will affect the quality of the data produced. One of them is missing data. To solve the problem of missing data, one method that can be used is data imputation. One type of machine learningbased imputation method that is often used is the Weighted KNNI. The Weighted KNNI method has generally better accuracy than the other two imputation methods (Unweighted KNNI and Mean Imputation). Based on these results, seen from its accuracy, the KNNI Weighted method can be used as a solution to dealing with incomplete data during the current COVID19 pandemic. 
Seminar Nasional Official Statistics 2019: Pengembangan Official Statistics dalam mendukung Implementasi SDG's

Keywords: missing data, KNNI, imputation 


\section{PENDAHULUAN}

Pada tahun 2020, hampir semua negara di dunia menghadapi wabah COVID-19, termasuk Indonesia. Salah satu dampak yang terjadi karena adanya pandemi COVID-19 adalah terhambatnya kegiatan statistik, seperti tertundanya atau berhentinya pelaksanaan pengumpulan data survei dan sensus serta pengumpulan data lainnya. Berdasarkan hasil survei yang dilakukan oleh United Nations Statistics Division dan World Bank, ada 56 persen kasus negara yang harus menghentikan pekerjaan lapangan sensus dan ada 37 persen kasus negara yang harus menunda/menghentikan pekerjaan lapangan survei yang direncanakan selama masa pandemi COVID-19.

Sementara itu, untuk memenuhi permintaan dan kebutuhan data selama masa pandemi COVID-19, badan statistik nasional harus tetap melakukan pengumpulan data dan menyediakan data statistik. Oleh sebab itu, badan statistik nasional harus melakukan adaptasi untuk kegiatan proses sensus dan survei yang dilakukan, seperti mencari mode pengumpulan data alternatif, mengurangi ukuran sampel, memodifikasi desain sampel, mengurangi item pertanyaan di kuesioner, atau lainnya. Ada 69 persen badan statistik nasional yang menghentikan kegiatan pengumpulan data secara tatap muka langsung atau wawancara (UN, 2020). Namun, perubahan metodologi pencacahan atau pengumpulan data yang drastis tidak direkomendasikan, misalnya mengubah metode wawancara atau tatap muka langsung menjadi metode self-enumeration secara daring (The Committee for the Coordination of Statistical Activities (CCSA), 2020).

Berdasarkan uraian tersebut, adaptasi kegiatan pengumpulan data sensus/survei yang dilakukan pada masa pandemi COVID-19 akan berpengaruh pada kualitas data yang dihasilkan. Salah satu masalah yang berkaitan dengan kualitas data statistik adalah adanya data yang tidak lengkap atau data yang hilang (missing value/ missing data) (Batista dan Monard, 2002). Pearson (2005) menjelaskan bahwa missing data tidak hanya berupa data yang tidak lengkap, tetapi juga dapat muncul dalam bentuk outlier atau nilai yang tidak konsisten dengan nilai sebelumnya, ataupun isian yang tidak wajar (Luengo, J, 2009). Missing data tersebut biasanya terjadi pada data hasil survei atau sensus karena beberapa hal, seperti adanya responden yang tidak mau ditemui atau diwawancarai, penolakan responden untuk menjawab pertanyaan tertentu, kegagalan/kerusakan peralatan baik saat proses input data maupun editing data, dan lainnya.

Untuk mengatasi masalah missing data, salah satu metode yang dapat digunakan adalah imputasi data, dengan tujuan untuk mengisi atau mengganti nilai yang mengandung missing data pada dataset sehingga dataset yang semula tidak lengkap menjadi lengkap tanpa mengurangi jumlah unit data yang di observasi dan dataset tersebut dapat digunakan untuk analisis lebih lanjut secara efisien. Ada berbagai metode imputasi yang berkembang saat ini. Menurut Jerez, et al (2010) salah satu jenis metode adalah metode imputasi berbasis machine learning. Salah satu jenis metode imputasi berbasis machine learning yang sering digunakan adalah $K$-Nearest Neighbor Imputation (KNNI). Penelitian yang dilakukan oleh Troyaska (2001), Batista dan Monard (2002), Azizah (2016), dan Fadillah dan Muchlisoh (2019) menjelaskan bahwa KNNI adalah salah satu metode imputasi terbaik.

Penelitian ini bertujuan untuk membandingkan beberapa metode imputasi sehingga diperoleh metode imputasi yang efisien dalam mengatasi permasalahan missing data/missing value pada dataset. Metode imputasi yang digunakan pada penelitian ini adalah metode Weighted KNNI. Hasil imputasi dari Weighted KNNI akan dibandingkan dengan metode Unweighted KNNI dan juga Mean Imputation. Dalam melakukan perbandingan metode imputasi tersebut, dataset yang digunakan pada penelitian ini adalah data Indeks Produksi Triwulanan Industri Mikro Kecil (IMK) menurut 2digit KBLI Tahun 2016 sampai 2019. 


\section{METODE}

Mean Imputation pada dasarnya adalah imputasi sederhana menggunakan nilai rata-rata dari data yang ada untuk diimputasikan pada data yang mengandung missing. Sedangkan, imputasi menggunakan metode KNNI didasarkan pada pengamatan donor. KNNI memanfaatkan jarak terdekat dengan objek terkait sebagai donor untuk melakukan imputasi pada missing data. Sudirman (2012) menjelaskan bahwa dalam melakukan imputasi, prinsip yang digunakan pada metode KNNI adalah dengan melakukan training terhadap data kemudian memperhatikan jarak terdekat dengan objek terkait yaitu tetangga terdekatnya dari data yang mengalami missing data yang berada pada kelas yang sama. Sebelum melakukan imputasi menggunakan metode KNNI, perlu ditentukan jumlah tetangga terdekat (k) yang akan digunakan sebelumnya. Banyak pendapat yang menjelaskan cara menentukan $\mathrm{k}$ yang akan digunakan. Troyaska, Olga, et. Al. (2001), menjelaskan bahwa metode imputasi KNNI menjadi kurang sensitif pada nilai k diatas 10. Suyundikov (2015) menjelaskan bahwa pilihan nilai k berpengaruh terhadap akurasi dan performa komputasinya, nilai k yang terlalu kecil mungkin dapat mengurangi keakuratan nilai imputasi, namun sebaliknya semakin besar nilai $k$ yang digunakan akan berakibat pada penurunan performa komputasi (Fadillah dan Muchlisoh, 2019).

Seperti yang telah dijelaskan, bahwa metode KNNI didasarkan pada pengamatan donor berdasarkan jarak terdekat. Jarak terdekat ini dihitung dengan berbagai metode perhitungan jarak, seperti jarak euclidean, manhattan, gower, dan sebagainya. Dalam penelitian ini, metode perhitungan jarak yang akan digunakan adalah gower distance. Adapun rumus perhitungan gower distance yang dirumuskan oleh Kowarik (2016) adalah sebagai berikut:

(1)

untuk data nominal dan binary adalah

(2)

untuk data kontinyu

(3)

Keterangan:

: Jarak observasi i ke j

: Banyaknya variabel prediktor

: Jarak observasi i ke j pada variabel $p$

: Nilai variabel ke-p pada observasi ke-i

: Nilai variabel ke-p pada observasi ke-j

: Range pada variabel $p$

Setelah itu, jarak digunakan sebagai penentu jarak terdekat sesuai dengan nilai k yang ditentukan. Untuk metode unweighted KNNI, nilai missing data akan diambil dari nilai median dari setiap donor yang ada. Sedangkan, untuk metode Weighted KNNI, nilai missing data akan diambil dari nilai rata-rata tertimbang dari $\mathrm{k}$ tetangga terdekatnya dengan jarak sebagai penentu dalam pembobotannya. Adapun rumus perhitungan tersebut yang dirumuskan oleh Kowarik (2016) adalah sebagai berikut: 
Keterangan:

: banyaknya tetangga terdekat

: nilai variabel missing data pada observasi ke-j

: nilai variabel donor pada observasi ke-i pada tetangga ke-k

: bobot variabel tetangga ke-k

: jarak observasi i ke j tetangga ke-k

Dalam penelitian ini, analisis akan dilakukan dengan metode simulasi dalam tiga tahap. Tahap pertama adalah pembentukan dataset yang mengandung missing data dengan mekanisme Missing Completely at Random (MCAR) pada tingkatan 10\%, 20\%, 30\%, 40\%, dan 50\%. Dalam melakukan perbandingan metode imputasi tersebut, dataset yang digunakan pada penelitian ini adalah data Indeks Produksi Triwulanan Industri Mikro Kecil (IMK) menurut 2-digit KBLI Tahun 2016 sampai 2019. Kemudian, tahap kedua adalah melakukan imputasi data menggunakan metode Mean Imputation, Weighted KNNI, dan Unweighted KNNI. Nilai k yang akan digunakan adalah sebesar 5 dan 10. Tahap ketiga adalah analisis hasil ketepatan estimator menggunakan RMSE (Root Mean Square Error) dan MAPE (Mean Absolute Percentage Error). Ketiga tahap ini akan dilakukan secara berulang sebanyak sepuluh kali untuk menghasilkan hasil imputasi yang lebih konsisten, kemudian nilai rata-rata dari pengulangan tersebut akan digunakan untuk dianalisis. Adapun rumus perhitungan RMSE dan MAPE adalah sebagai berikut:

Keterangan:

: nilai prediksi observasi ke-i

: nilai aktual observasi ke-i

: jumlah peramalan

\section{HASIL DAN PEMBAHASAN}

\section{Perbandingan Ketepatan Estimator}

Gambar 1 dan Gambar 2 menunjukkan hasil kinerja imputasi yang dihasilkan dengan menggunakan metode Mean Imputation, Weighted KNNI, dan Unweighted KNNI. Secara umum, hasil tersebut menunjukkan bahwa metode KNNI menghasilkan ketepatan estimator yang lebih baik daripada metode Mean Imputation. Hal ini ditunjukkan dari nilai RMSE dan MAPE yang lebih rendah pada tiap persentase missing data yang ada. Sementara itu, jika dilihat dari metode KNNI, metode Weighted KNNI menghasilkan ketepatan estimator yang secara konsisten lebih baik dibandingkan metode Unweighted KNNI pada nilai k sebesar 10. Sedangkan, untuk nilai k sebesar 5, pada persentase missing data yang tidak terlalu besar (10 persen dan 20 persen) Unweighted KNNI memberikan hasil yang sedikit lebih baik dibandingkan metode Weighted KNNI, dan untuk persentase missing data diatas 20 persen, metode Weighted KNNI cenderung memberikan hasil yang lebih baik. Adapun jika dilihat dari nilai k yang digunakan, baik metode Weighted KNNI maupun Unweighted KNNI dengan nilai k sama dengan 5 memiliki ketepatan estimator yang lebih baik dari pada dengan nilai $\mathrm{k}$ sama dengan 10 sehingga, pada penelitian ini nilai $\mathrm{k}$ sama dengan 5 
lebih optimum dibandingkang 10 untuk menghasilkan nilai RMSE dan nilai MAPE yang lebih rendah.

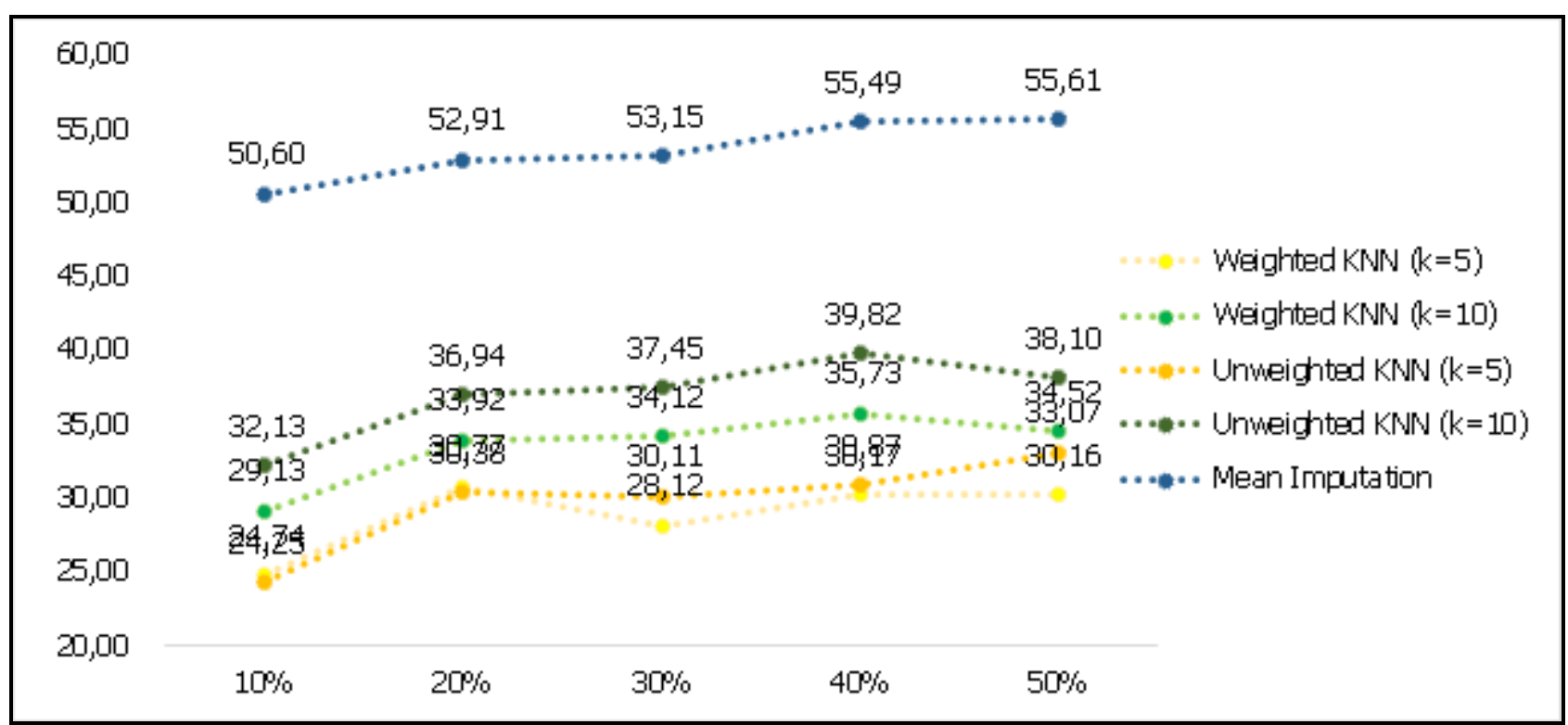

Gambar 1. Perbandingan RMSE dari Metode KNNI dan Mean Imputation.

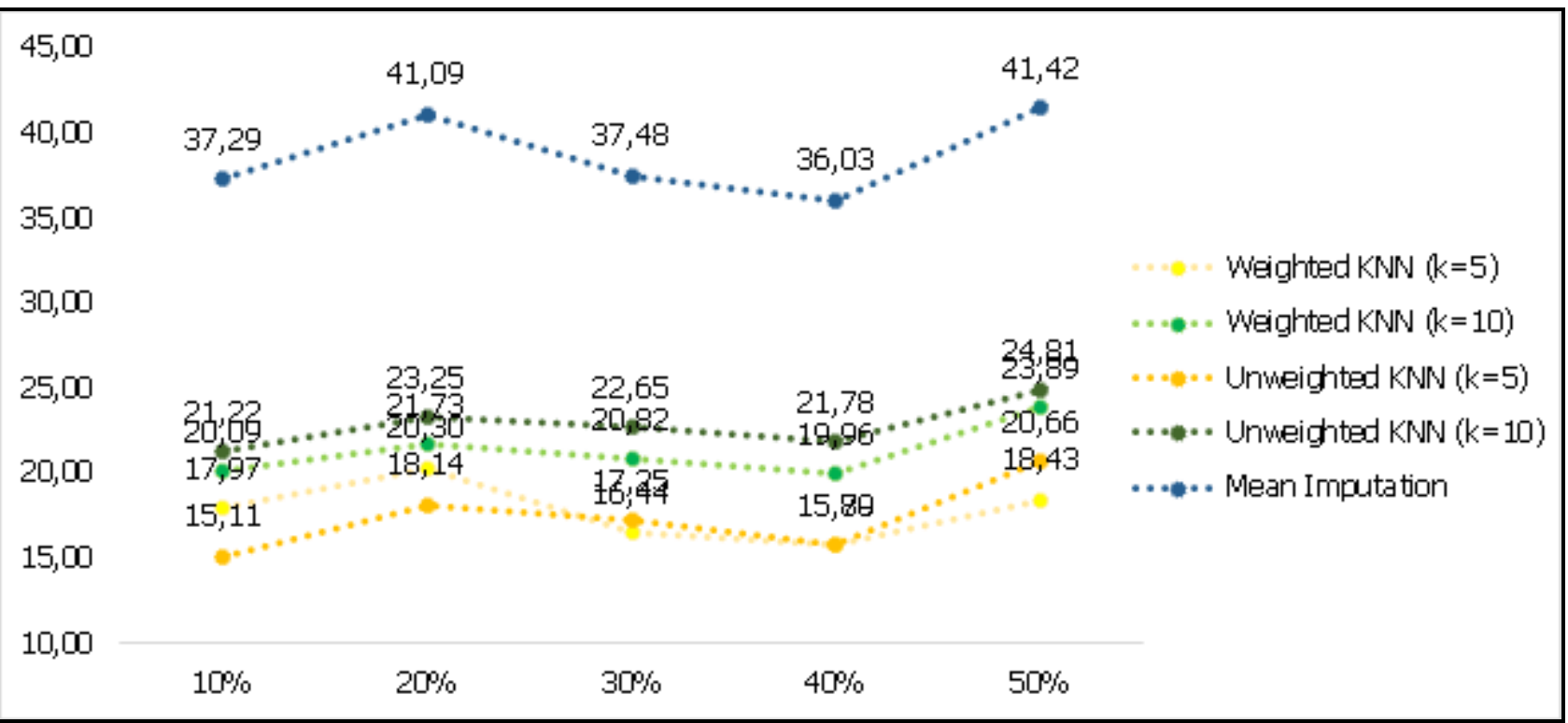

Gambar 2. Perbandingan MAPE dari Metode KNNI dan Mean Imputation.

\section{Analisis Perbandingan Metode K-Nearest Neighbor Imputation (KNNI) dan Metode Mean Imputation}

Berdasarkan hasil analisis sebelumnya, dapat dilakukan analisis lebih lanjut mengenai perbandingan hasil imputasi dari metode KNNI, baik Weighted KNNI maupun Unweighted KNNI, dan metode Mean Imputation. Dari hasil simulasi yang telah dilakukan, metode KNNI menghasilkan ketepatan estimator yang secara konsisten lebih baik daripada metode Mean Imputation. Hal ini ditunjukkan dari nilai RMSE dan MAPE yang lebih rendah untuk setiap tingkatan missing data. Sementara itu, jika dilihat dari metode KNNI, imputasi dengan menggunakan metode Weighted KNNI akan lebih menghasilkan akurasi ketepatan estimator yang lebih baik dari pada menggunakan metode Unweighted KNNI. Namun, secara umum, nilai RMSE dan nilai MAPE akan semakin meningkat seiring dengan bertambahnya persentase ketidaklengkapan data. 
Tabel 1. RMSE tiap metode per persentase missing data

\begin{tabular}{cccccc}
\hline \multirow{2}{*}{ Missing Data } & \multicolumn{5}{c}{ WMSE } \\
\cline { 2 - 4 } & \multicolumn{2}{c}{$\mathrm{K}=5$} & $\mathrm{~K}=10$ & $\mathrm{~K}=5$ & \multirow{2}{*}{ Mean Imputation } \\
\cline { 2 - 5 } $10 \%$ & 24,74 & 29,13 & 24,25 & 32,13 & 50,60 \\
$20 \%$ & 30,77 & 33,92 & 30,38 & 36,94 & 52,91 \\
$30 \%$ & 28,12 & 34,12 & 30,11 & 37,45 & 53,15 \\
$40 \%$ & 30,17 & 35,73 & 30,87 & 39,82 & 55,49 \\
$50 \%$ & 30,16 & 34,52 & 33,07 & 38,10 & 55,61 \\
\hline
\end{tabular}

Tabel 2. MAPE tiap metode per persentase missing data

\begin{tabular}{|c|c|c|c|c|c|}
\hline \multirow{3}{*}{ Missing Data } & \multicolumn{5}{|c|}{ MAPE } \\
\hline & \multicolumn{2}{|c|}{ Weighted KNNI } & \multicolumn{2}{|c|}{ Unweighted KNNI } & \multirow{2}{*}{ Mean Imputation } \\
\hline & $K=5$ & $K=10$ & $K=5$ & $\mathrm{~K}=10$ & \\
\hline $10 \%$ & $17.97 \%$ & $20,09 \%$ & $15.11 \%$ & $21,22 \%$ & $37,29 \%$ \\
\hline $20 \%$ & $20.30 \%$ & $21,73 \%$ & $18.14 \%$ & $23,25 \%$ & $41,09 \%$ \\
\hline $30 \%$ & $16.44 \%$ & $20,82 \%$ & $17.25 \%$ & $22,65 \%$ & $37,48 \%$ \\
\hline $40 \%$ & $15.80 \%$ & $19,96 \%$ & $15.79 \%$ & $21,78 \%$ & $36,03 \%$ \\
\hline $50 \%$ & $18.43 \%$ & $23,89 \%$ & $20.66 \%$ & $24,81 \%$ & $41,42 \%$ \\
\hline
\end{tabular}

Adapun jika dilihat dari nilai k, metode KNNI dengan menggunakan nilai k sama dengan 5 menghasilkan ketepatan estimator yang lebih akurat dibandingkan metode KNNI dengan menggunakan nilai $\mathrm{k}$ sama dengan 10 . Hal tersebut menunjukkan bahwa nilai $\mathrm{k}$ sama dengan 5 lebih optimum digunakan untuk imputasi data Indeks Produksi Triwulanan Industri Mikro Kecil (IMK) menurut 2-digit KBLI Tahun 2016 sampai 2019 dibandingkan nilai k sama dengan 10 untuk menghasilkan akurasi yang lebih baik, yaitu baik dari nilai RMSE maupun nilai MAPE yang lebih rendah. Namun, alternatif yang dapat dilakukan jika ingin meningkatkan ketepatan estimator adalah dengan melakukan analisis lebih lanjut untuk memilih nilai $\mathrm{k}$ optimum sebelum melakukan imputasi data.

Oleh karena itu, maka dalam penggunaan metode KNNI sebagai salah satu metode imputasi missing data penting untuk menentukan nilai $\mathrm{k}$ yang akan digunakan dengan menyesuaikan tipe dan jumlah data yang tersedia. Pemilihan nilai k yang besar pada umumnya akan meningkatkan ketepatan dari hasil imputasi yang dihasilkan. Namun, hal ini berlaku jika jumlah data yang tersedia cukup besar. Oleh karenanya, untuk kasus dengan jumlah data yang sedikit seperti pada penelitian ini, maka penggunaan nilai $\mathrm{k}$ dalam jumlah yang lebih kecil perlu dipertimbangan, selain terkait akurasi, juga terkait waktu yang diperlukan dalam melakukan proses imputasi.

\section{KESIMPULAN}

Berdasarkan hasil analisis dan pembahasan yang telah dilakukan, implementasi metode Mean Imputation, Weighted KNNI, dan Unweighted KNNI pada data Indeks Produksi Triwulanan Industri Mikro Kecil (IMK) menurut 2-digit KBLI Tahun 2016 sampai 2019 menunjukkan bahwa, metode KNNI (Weighted KNNI dan Unweighted KNNI) menghasilkan hasil imputasi yang secara konsisten lebih baik dibandingkan metode Mean Imputation baik akurasi dari nilai RMSE maupun akurasi dari nilai MAPE. Namun, dari kedua metode KNNI, metode Weighted KNNI memiliki akurasi yang paling baik sehingga metode tersebut dapat digunakan sebagai salah satu solusi untuk menangani permasalahan terkait ketidaklengkapan data yang terjadi pada masa pandemi COVID19.

Penggunaan metode Weighted KNNI dan Unweighted KNNI sangat dipengaruhi oleh nilai $\mathrm{k}$ yang digunakan, jika dalam pemilihan k optimum, nilai k optimum yang digunakan cukup besar, 
serta persentase missing data juga cukup besar, penggunakan metode Weighted KNNI lebih disarankan dibandingkan metode Unweighted KNNI. Namun, jika nilai k optimum yang didapat cukup kecil dan persentase missing data tidak terlalu banyak, kedua jenis metode KNNI dapat dipertimbangan untuk melakukan proses imputasi.

\section{DAFTAR PUSTAKA}

Azizah Nur. (2016). Analisis Perbandingan Metode Multiple Imputation dan KNearest Neighbor Imputation dalam Mengatasi Missing Data. [Skripsi]. Sekolah Tinggi Ilmu Statistik Jakarta.

Badan Pusat Statistik. (2020). Indeks Produksi Triwulanan Industri Mikro Kecil (IMK) menurut 2-digit KBLI Tahun 2016 sampai 2019. Jakarta: BPS.

Batista, Gustavo E. A. P. A. dan Maria Carolina Monard. (2002). A Study of K-Nearest Neighbour as an Imputation Method. Second International Conference on Hybrid Intelligence, 8.

Fadillah, Iman J., dan Muchlisoh, Siti (2019). Perbandingan Metode Hot-Deck Imputation dan Metode KNNI dalam Mengatasi Missing Values. Prosiding Seminar Nasional Official Statistics. 2019. Politeknik Statistika STIS. Jakarta. https://doi.org/10.34123/semnasoffstat.v2019i1.101

Jerez, J.M., dan Molina, I., (2010). Missing data imputation using statistical and machine learning methods in a real breast cancer problem. Artificial intelligence in medicine, 105-115.

Kowarik, Alexander., dan Templ, Matthias (2016), Imputation with the R Package VIM. Journal of Statistical. Foundation for Open Access Statistics, vol. 74(i07).

Luengo, J. (2009). A study on the use of imputation methods for experimentation with Radial Basis Function Network classifiers handling missing attribute values: The good synergy between RBFNs and EventCovering method. Elsevier Ltd.

Sudirman. (2012). Analisis Perbandingan Metode Imputasi Missing valuess Global dan Concept Method pada Data Supervised. Jakarta: Universitas Mercu Buana.

Suyundikov, Anvar et. al. (2015). Accounting for Dependence Induced by Weighted KNN Imputation in Paired Samples, Motivated by a Colorectal Cancer Study. Taiwan: National Taiwan University.

The Committee for the Coordination of Statistical Activities (CCSA). (2020). How COVID-19 is changing the world: a statistical perspective. Cited in https://unstats.un.org/unsd/ccsa/documents/covid19-reportccsa.pdf.

Troyaska, Olga, et. Al. (2001). Missing value estimation methods for DNA microarrays. Bioinformatics, 17:520-525.

United Nations, Statistics Division. (2020). Monitoring the state of statistical operations under the COVID-19 Pandemic. Cited in https://unstats.un.org/unsd/covid19-response/covid19-nso-survey-report.pdf 